\title{
Short-time effect of harvesting methods on soil respiration dynamics in a beech forest in southern Mediterranean Italy
}

\author{
Vittoria Coletta ${ }^{(1)}$, \\ Gaetano Pellicone (2), \\ Vincenzo Bernardini ${ }^{(3)}$, \\ Bruno De Cinti ${ }^{(4)}$, \\ Raffaele Froio ${ }^{(2)}$, \\ Pasquale A Marziliano (1), \\ Giorgio Matteucci ${ }^{(2)}$, \\ Nicola Ricca ${ }^{(2)}$, \\ Rosario Turco(3), \\ Antonella Veltri ${ }^{(2)}$
}

\begin{abstract}
$\mathrm{CO}_{2}$ fluxes from soil, together with soil water content and temperature have been measured over one solar year in an even-aged beech forest (Fagus Sylvatica $L$.) in southern Italy. We investigated the effects of three different harvested biomass removal treatments (traditional, innovative, unharvested control) on soil respiration $\left(R_{s}\right)$ in three plots from May 2014 to April 2015, with the aim to evaluate the effects of such silvicultural practices on the $\mathrm{CO}_{2}$ respired from the forest floor. The influence of soil temperature and soil moisture on soil respiration was also analysed. $R_{\mathrm{s}}$ showed large variations among the treatments, with the innovative treatment resulting in significantly higher soil respiration than control and traditional treatments. There were no significant differences in soil temperature between the treatments, whereas soil water content was statistically different only in the innovative treatment. The study showed that the mean soil respiration increased with thinning intensity, confirming that after harvesting, residues remaining on the forest floor and decomposing roots may contribute to raise soil respiration, due to the higher microbial activity.
\end{abstract}

\section{Keywords: Soil Respiration, $\mathrm{CO}_{2}$, Forest Management, Beech Forest}

photosynthetic activity and soil respiration (Sampson et al. 2007). Soil temperature can be used to predict rates of soil respiration through a sensitivity coefficient of soil respiration, commonly referred to as $\mathrm{Q}_{10}$ and used to describe the difference in rates of soil respiration over $10{ }^{\circ} \mathrm{C}$ temperature intervals (Lloyd \& Taylor 1994). Variations in soil moisture content are also accounted for, as this last variable is, together with soil temperature, the most important environmental parameter controlling variations in soil $\mathrm{CO}_{2}$ efflux (Reichstein et al. 2003).

Given the temperature dependence of soil respiration, a potential positive feedback between increasing temperature and enhanced soil respiration may ultimately accelerate global warming (Trumbore 1997, Grace \& Rayment 2000, Davidson et al. 2000, Schlesinger \& Andrews 2000, Rodeghiero \& Cescatti 2005). Scientists are $\square$ (1) Mediterranean University of Reggio Calabria, Feo di Vito, 89020 Reggio Calabria (Italy); (2) Institute for Agricultural and Forest Systems in the Mediterranean (ISAFOM), National Research Council of Italy, Cosenza (Italy); (3) Mediterranean Forestry Research Unit, (CRA-SAM). Rende, Cosenza (Italy); (4) Institute of Agro-envinronmental and Forest Biology (IBAF), National Research Council of Italy, Montelibretti (RM, Italy)

@ Gaetano Pellicone (gaetano.pellicone@isafom.cnr.it)

Received: Mar 01, 2016 - Accepted: Apr 08, 2017

Citation: Coletta V, Pellicone G, Bernardini V, De Cinti B, Froio R, Marziliano PA, Matteucci G, Ricca N, Turco R, Veltri A (2017). Short-time effect of harvesting methods on soil respiration dynamics in a beech forest in southern Mediterranean Italy. iForest 10: 645-651. - doi: 10.3832/ifor2032-010 [online 2017-06-20]

Communicated by: Giorgio Alberti therefore particularly interested in studying forest management strategies aimed at promoting C storage (Kurth et al. 2014, Marziliano et al. 2015a, 2015b). Forest management has thus important effects on both autotrophic and heterotrophic soil respiration, contributing to affect local microclimatic properties of the soil, soil microbial communities and litter input (Olajuyigbe et al. 2012) through biomass removal and the opening of the forest canopy (Masyagina et al. 2010). Forest management can potentially affect the $Q_{10}$ of soil respiration by changing substrate availability and photosynthetic activity (Gershenson et al. 2009), root activity and inputs of labile organic carbon (Kuzyakov et al. 2000, Zhu \& Cheng 2011), and soil temperature and moisture (Davidson \& Janssens 2006). The consequences of forestry practices on $C$ balances and $\mathrm{CO}_{2}$ emissions from the soil are still poorly understood in terms of their impact on global C flux (Akburak \& Makineci 2016). The effect of thinning on soil respiration largely depends on the type, intensity and timing of the intervention (Cheng et al. 2014).

From May 2014 to April 2015, within ManFor.BD Life project, $\mathrm{CO}_{2}$ fluxes from soil, together with soil water content and temperature have been measured over one solar year in an even-aged beech forest (Fagus sylvatica L.) under three different management options in southern Italy. Beech forests are among the most common forest communities in Italy, from the Alps to the Apennines including Sicily. In Calabria they have been, along with chestnut and silver-fir, a fundamental resource 
Fig. 1 - Representation of the nine areas managed with three different treatments ( $\mathrm{Al} 2$ innovative, $\mathrm{AC} 3$ control and AT6 traditional) and the sampling circular plots. Areas where soil respiration measurements were carried out are within the circles.

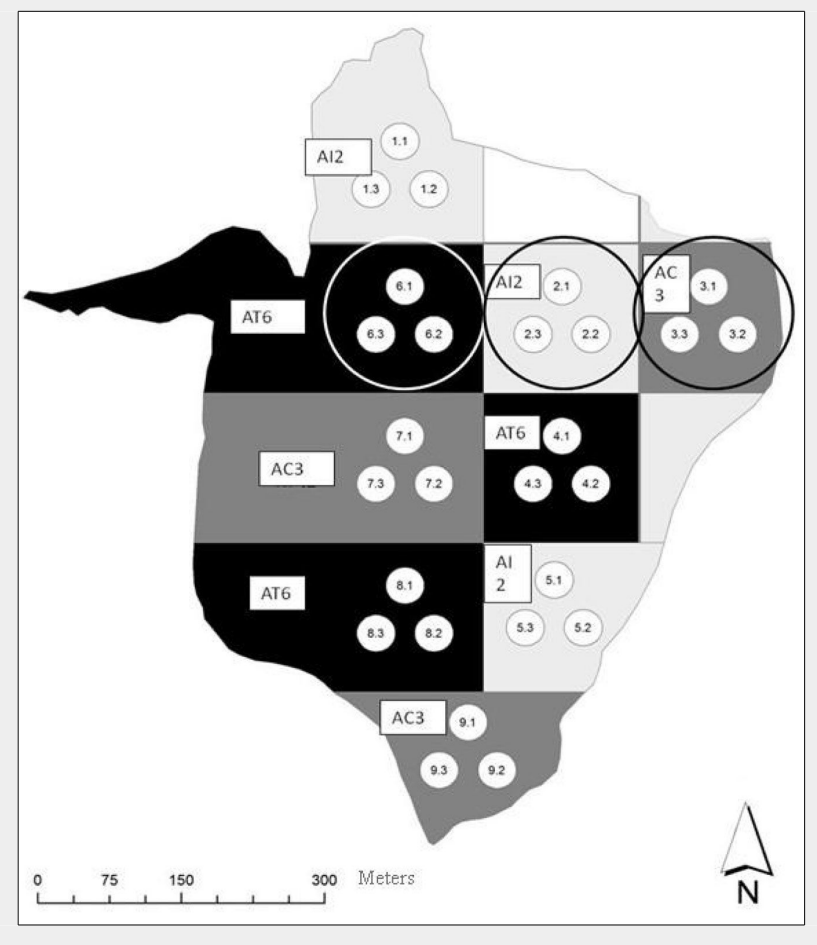

for people living in mountain areas, being used mainly for firewood and charcoal as well as timber for building and furniture (Marziliano et al. 2012) and this intensive use has significantly modified the distribution, composition and structure of beech stands (Nocentini 2009). The management of these forest stands should be aimed to ensure that the benefits - both material and intangible - meet present needs, while at the same time ensuring their continued availability and contribution to long-term social and economic development (sustainable management). Here, we investigated the effects on soil respiration of three different silvicultural treatments: (i) thinning from below (traditional treatment), which consisted in the elimination of the worst trees in the dominated layer; (ii) tree-oriented silviculture (innovative thinning sensu Kerr 1996) which aimed to diversify forest structure through the creation of heterogeneous gaps; and (iii) no thinning (control). evaluate the ecological effects of management, with a focus on the influence on carbon uptake/loss from forest soil. We investigated the hypothesis that an innovative silviculture based on tree-oriented silviculture, in addition to being a sustainable outputs from soil.
This experimental study was conceived to

treatment which modifies growing spaces and spatial niches to increase heterogeneity of the stand structure, can also reduce $C$

The main aim of this study was to evaluate the effect of such silvicultural practices on the $\mathrm{CO}_{2}$ respired from the forest floor. A secondary objective was to analyse the influence of soil temperature and soil moisture on soil respiration.

\section{Material and methods}

\section{Site description and experimental} design

The study area is located in the Marchesale Biogenetic Reserve (a Natura 2000 site) in Mongiana, the highest side of calabrian "Serre" mountains, within the province of Vibo Valentia $\left(38^{\circ} 30^{\prime} \mathrm{N}, 16^{\circ} 14^{\prime} \mathrm{E}\right)$. The whole reserve is 1257 ha wide, with altitude ranging between 750 and $1170 \mathrm{~m}$ a.s.l. and it is managed by the National Forest Service of Italy (CFS). The forest types are beech forest managed as high forest and chestnut stands managed as coppice. In the area there is a small fraction of mixed beech-fir high forest (5\%). The understorey is mainly composed of penciled geranium (Geranium versicolor L.) and Caucasian leopard's bane (Doronicum orientale

Tab. 1 - Main dendrometric characteristics ( \pm standard deviation) of Al2 (innovative), AT6 (traditional), AC3 (control) treatments.

\begin{tabular}{llccc}
\hline Treatment & $\begin{array}{c}\text { Volume } \\
\left(\mathbf{m}^{3} \mathbf{h a}^{-1}\right)\end{array}$ & $\begin{array}{c}\text { Basal area } \\
\left(\mathbf{m ~}^{2} \text { ha-1 }\right.\end{array}$ & $\begin{array}{c}\text { No. tree } \\
(\mathbf{N ~ h a}\end{array}$ \\
\hline Al2 (innovative) $)$ & Before & $338.1 \pm 27.7$ & $33.9 \pm 1.9$ & $631 \pm 104.4$ \\
& After & $246.1 \pm 21.3$ & $26.6 \pm 1.6$ & $533 \pm 94.3$ \\
AT6 (traditional) & Before & $345.7 \pm 19.8$ & $34.0 \pm 1.2$ & $557 \pm 138.7$ \\
& After & $301.6 \pm 15.6$ & $29.7 \pm 1.0$ & $501 \pm 111.5$ \\
AC3 (control) & - & $432.9 \pm 174.1$ & $38.5 \pm 11.4$ & $334 \pm 201.2$ \\
\hline
\end{tabular}

Hoffm.). The climate is typical upland Mediterranean (Csb, sensu Koppen 1936) with a long-term (1928-2012) mean annual temperature and precipitation of $10.1{ }^{\circ} \mathrm{C}$ and $1880 \mathrm{~mm}$, respectively. The warmest month is July $\left(18.4^{\circ} \mathrm{C}\right)$, the coldest month is February $\left(2.2{ }^{\circ} \mathrm{C}\right.$ - average of 30 years measurements).

The study area is characterized by Palaeozoic granitoid rocks deeply fractured, the morphology is dominated by a mountains landscape with deep, V-shaped valleys (Conforti et al. 2015). According to USDA soil classification (Soil Survey Staff 2010), the most frequent soils are Inceptisols and Entisols, with soil from shallow to moderatly deep (0.20-1.0 m), coarse-textured and acidic pH (3.7-5.8 - Conforti et al. 2013).

Within the ManFor C.BD. project, a 30 ha stand of 75-year-old high forest of beech at $1100 \mathrm{~m}$ elevation was selected and nine areas from 2.8 to 3.5 ha were subjected to three silvicultural thinnings ( 3 treatments $\times$ 3 replicates; 2012-2013 - Fig. 1). Before carrying out silvicultural treatments, statistical differences between dendrometric parameters were analyzed, resulting not significant (Picchio et al. 2016).

The options were traditional treatments (thinning from below - AT6), innovative treatments based on the tree-oriented silviculture (Al2) and unharvested control (AC3 - Tab. 1). Traditional treatment was a thinning from below with a moderate intensity, which removed all the dominated trees and the worst dominant trees competing with the best dominant ones (on average $45 \%$ trees cut). Innovative treatment was aimed at favouring the 50 best tress per hectare and enhancing structural biodiversity, by harvesting 5 or 6 closest competitor trees of the target trees, irrespective of their social position. Within each treatment, 3 randomly selected circular plots with a $17 \mathrm{~m}$ radius were chosen. Soil respiration measurements were conducted for one year within each circular plot at six PVC collars ( $5 \mathrm{~cm}$ height, $10 \mathrm{~cm}$ diameter) inserted into the soil to a depth of $5 \mathrm{~cm}$. Once inserted, rings were left in place in the field throughout the year. They were spaced according to a "spiral arrangement" inscribed in a $13 \mathrm{~m}$ radius circle. The first one was randomly placed close to the plot centre, the second one at three meters from the centre along the line of maximum slope and the other four were placed at an increasing distance from the centre of $6,9,12$, and $12 \mathrm{~m}$ respectively, with an angle of 90 degrees from the imaginary line connecting the centre to the collar inserted beforehand. The last collar at the $12 \mathrm{~m}$ distance from the centre was inserted according to the maximum slope. A portable chamber (SRC-1 soil respiration chamber, stainless steel, $15 \mathrm{~cm}$ height, 10 $\mathrm{cm}$ diameter) was used to measure $\mathrm{CO}_{2}$ efflux by connecting it to a portable gasanalyzer EGM-4 (Environmental Gas Monitor - PP-systems, Hitchin, Hertfordshire, UK). Fluxes of $\mathrm{CO}_{2}$ were measured by circu- 
lating air between a vented, chamber placed over the PVC ring and the portable battery operated EGM-4. The experiment commenced in May 2014, with biweekly measurements until May 2015, apart from the months of December and January, when measurements were suspended due to snowpack. Flux measurements were made between 11:00 and 15:00 hours at each of the 9 circular plots.

Soil temperature was measured adjacent to each PVC collar at the time of the flux measurement, with a digital soil thermometer (Spectrum Technologies, Aurora, Illinois, USA). The depth of the measurement was $10 \mathrm{~cm}$ below the top of the litter layer. Soil water content was measured by time domain reflectometry (TDR) with FieldScout TDR 100 Soil Moisture Meter (Spectrum Technologies, Aurora, IL, USA), with two-rod probes $12 \mathrm{~cm}$ long placed vertically into the soil in a randomly selected spot around each collar during each $\mathrm{CO}_{2}$ measurement. The output of the soil moisture meter was the percentage volume water content. Daily precipitation were obtained from a weather station installed at the launch of the project in the core of the high forest beech stand under consideration, at a distance of less than 1 kilometer from plots.

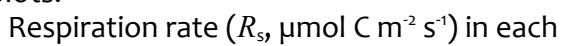
collar was calculated using the following equation (eqn. 1):

$$
R_{s}=\Delta C \cdot \frac{P V}{A T R}
$$

where $\Delta C$ (ppm) is the $\mathrm{CO}_{2}$ differential between the inlet and outlet, $P$ is the atmospheric pressure, $V$ is the volume of the headspace gas within the chamber, $A$ is the area of soil enclosed by the chamber, $T$ is the soil temperature $(\mathrm{K})$ and $R$ is the universal gas constant $\left(8.314 \mathrm{~J} \mathrm{~mol}^{-1} \mathrm{~K}^{-1}\right)$.

\section{Relationship between soil respiration,} temperature and moisture content

The relationship between soil temperature and soil respiration rate was fitted with an exponential model (eqn. 2):

$$
R_{s}=a \cdot e^{b T}
$$

where $R_{\mathrm{s}}$ is the measured soil respiration rate, $T$ is the measured soil temperature $\left({ }^{\circ} \mathrm{C}\right), a$ and $b$ are fitted parameters obtained using a least square non-linear regression. The temperature sensitivity index of soil respiration $\left(Q_{10}\right)$, representing the relative increase of $R_{\mathrm{s}}$ when temperature increases by $10{ }^{\circ} \mathrm{C}$ within feasible range, was calculated by exponential curve using the following equation (eqn. 3 ):

$$
Q_{10}=e^{10 b}
$$

In accordance with eqn. 2 and the method of Tang \& Baldocchi (2005), the following equation was used to describe the combined effect of temperature and moisture on soil respiration (eqn. 4):

$$
R_{s}=\left(b_{1} \cdot e^{b_{2} S o i l T}\right) \cdot e^{b_{3} S W C+b_{4} S W C^{2}}
$$

where SoilT is the Soil Temperature $\left({ }^{\circ} \mathrm{C}\right)$, $S W C$ is the soil water content (\%), $b_{1}, b_{2}, b_{3}$, and $b_{4}$ are the parameters of the non-linear regression.

\section{Statistical analyses}

One-way ANOVA test was used to compare $b$ values among treatments. The standard error (SE) of $Q_{10}$ was calculated as follows (Olajuyigbe et al. 2012 - eqn. 5):

$$
S E=Q_{10} \cdot 10 \cdot S E(b)
$$

After determination of the coefficient of variation ( $\mathrm{cv} \%$ ) between measurements at the six collars positions in each circular plot, the mean of respiration, temperature and moisture of the six collars were used to represent every plot.

The effect of treatments on soil temperature and soil water content was analyzed with a one-way ANOVA.

A repeated measures ANOVA, with significant differences determined at $a<0.05$, was used to test the differences of soil respiration between treatments. A Mauchly's test of sphericity was carried out to test homogeneity of variances.

The model was set up with the respiration rate measurements (average of the 18

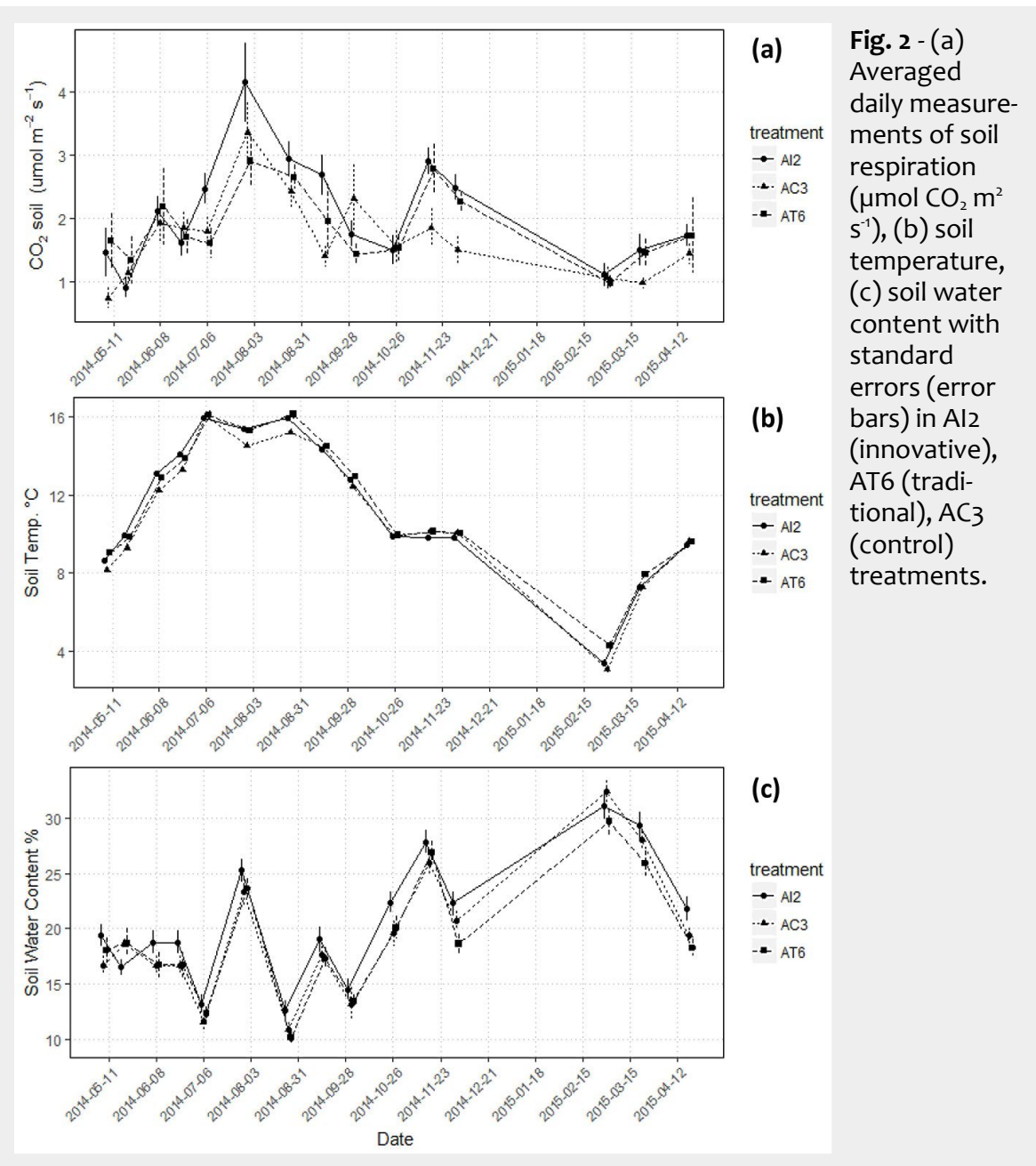

measurements from collars for any treatment) as the dependent variable, the treatments as a "between-subjects" factor, soil temperature and soil moisture as covariates. The interaction between treatment and date was also considered in the model. A post-hoc comparison was made using the Tukey's HSD test.

A non-linear regression analysis was used to evaluate the combined effect of soil temperature and soil water content on soil respiration for each treatment. The estimate of the parameters of the nonlinear regression model was based on the Gaussdard errors of the parameters were estimated by a bootstrapping algorithm (Efron \& Tibshirani 1993). The statistics RSME (root mean squared error), $R^{2}$ (coefficient of determination) and SEE (Standard Error of Estimate) were used for model evaluation. The regression model was applied to each treatment separately.

Statistical analyses were conducted using SPSS statistics ver. 21 for Windows (IBM Corp., Armonk, NY, USA).

\section{Results}

Seasonal variations and effects of soil temperature and soil moisture content on $R_{s}$

Fig. 2 shows the averaged daily measureNewton method (Seber \& Wild 1989). Stan- 


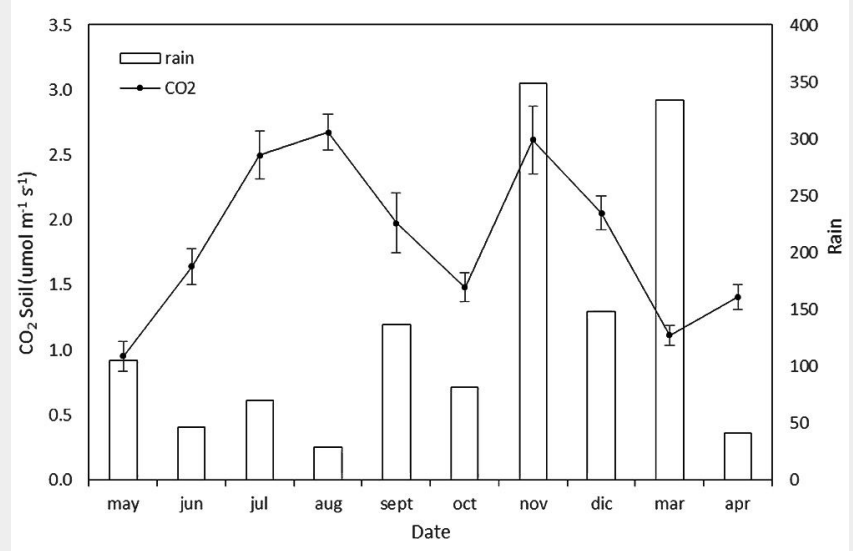

Fig. 3 - Soil respiration $\left(\mu \mathrm{mol} \mathrm{CO}_{2} \mathrm{~m}^{2} \mathrm{~s}^{-1}\right)$ and total monthly precipitation $(\mathrm{mm})$.

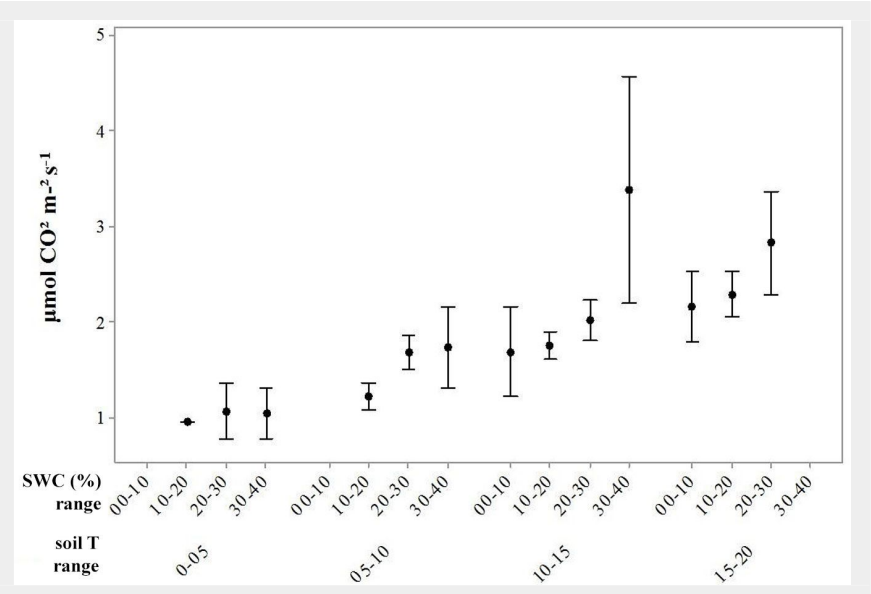

Fig. $4-\mathrm{CO}_{2}\left(\mu \mathrm{mol} \mathrm{CO}_{2} \mathrm{~m}^{2} \mathrm{~s}^{-1}\right)$ efflux with standard errors (error bars), recorded when soil water content (SWC) ranged from 0 to $40 \%$ and soil temperature (Soil T) ranged from o to $20^{\circ} \mathrm{C}$.

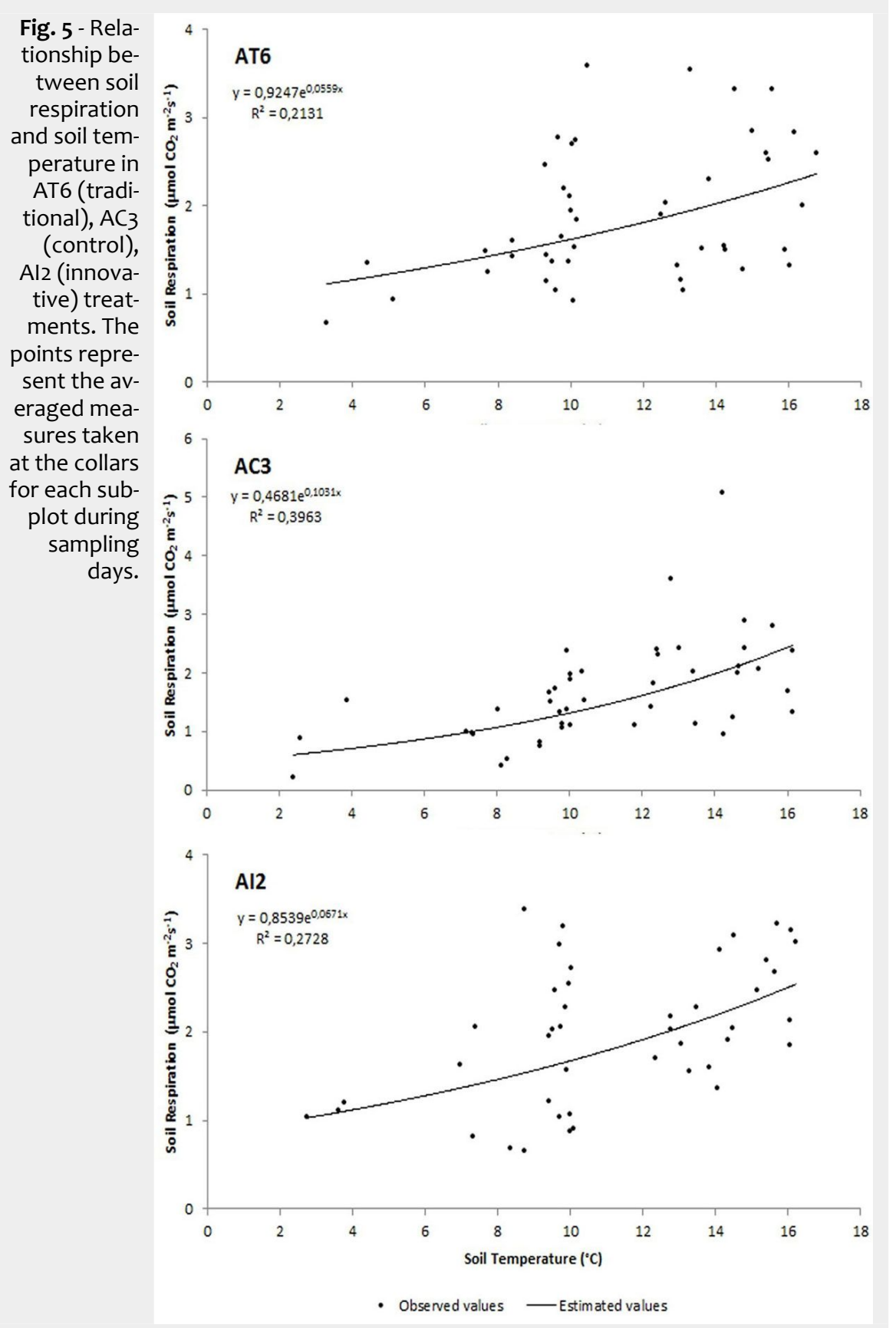

ments of $R_{\mathrm{s}}(\mathrm{a})$, soil temperature (b) and soil water content (c) for the whole campaign. Each value represents the mean of measurements taken at three plots per treatment (generally between 11:00 and 15:00 h) in every measurement day.

Soil respiration varied significantly over the year $(\mathrm{p}<0.001)$ for all treatments (Al2: from 0.91 to $4.2 \pm 0.85 \mu \mathrm{mol} \mathrm{CO}_{2} \mathrm{~m}^{-2} \mathrm{~s}^{-1} ; \mathrm{AC} 3$ : from 0.73 to $3.36 \pm 0.66 \mu \mathrm{mol} \mathrm{CO}_{2} \mathrm{~m}^{-2} \mathrm{~s}^{-1}$; AT6: from 0.98 to $2.90 \pm 0.57 \mu \mathrm{mol} \mathrm{CO} \mathrm{m}^{-2}$ $\left.\mathrm{s}^{-1}\right)$. Soil temperature and soil moisture also showed a significant seasonal variability $(\mathrm{p}<0.001)$.

$R_{\mathrm{s}}$ peaked during July to September and then dropped (Fig. 2a) in May (Al2 and AC3) and in March (AT6). Al2 had the highest averaged annual $\mathrm{CO}_{2}$ efflux from soil (2.09 $\left.\pm 0.85 \mu \mathrm{mol} \mathrm{CO} \mathrm{m}^{-2} \mathrm{~s}^{-1} ; \mathrm{p}<0.001\right), \mathrm{AC}_{3}$ the lowest $\left(1.68 \pm 0.66 \mu \mathrm{mol} \mathrm{CO}_{2} \mathrm{~m}^{-2} \mathrm{~s}^{-1}\right.$; $\mathrm{p}<0.001)$. In the warmest and driest period (August 2014 - Fig. 2a) AT6 showed the lowest emission from soil. Without considering the treatments, Fig. 3 shows that the month of July was less dry and warm than the rest of the summer months, resulting in a lower $R_{\mathrm{s}}$. November was a rainy month (348 mm - Fig. 3) and an increase of soil respiration occurred when soil water content raised.

Respiration was inhibited when soil temperature ranged between 0 and $5{ }^{\circ} \mathrm{C}$ with a soil moisture ranging between 10 and $20 \%$. The lowest efflux occurred when soil temperature was under $10{ }^{\circ} \mathrm{C}$ and soil water content was about $16 \%$ in $\mathrm{Al} 2$ and $\mathrm{AC} 3$. In AT6 the lowest $R_{\mathrm{s}}$ was recorded when soil temperature was $4{ }^{\circ} \mathrm{C}$ and soil water content was $29 \%$. Without considering the treatments, Fig. 4 shows that the highest soil emission occurred when soil temperature was recorded ranging from 10 and 15 ${ }^{\circ} \mathrm{C}$ and a soil water content was between 30 and $40 \%$.

$Q_{10}$ was $2.06 \pm 0.39$ in $\mathrm{AC} 3,1.94 \pm 0.41$ in $\mathrm{Al} 2$ and $1.74 \pm 0.38$ in AT6. No significant differences between $Q_{10}$ values were found $(p=0.262)$.

The one-way ANOVA showed that no sig- 
nificant effect of treatments on soil temperature was found $\left(F_{2 ; 708}=0.537 ; p=0.585\right)$, but treatments had a significant effect on soil water content $\left(F_{2 ; 088}=3.670 ; p=0.026\right)$.

Repeated measures ANOVA analysis showed that there were no significant differences in soil temperature between the treatments ( $p>0.05)$, whereas soil water content was statistically different only in Al2 $(p<0.001)$.

During the experimental period $R_{\mathrm{s}}$ showed a significant positive correlation to soil temperature in all the treatments $(p<0.0001)$. The exponential regression gave low $R^{2}$ values when considering averaged values for any day of measurements in each sub-plot $\left(R^{2}=0.21\right.$ for AT6; $R^{2}=0.40$ for $A C_{3} ; R^{2}=0.27$ for $A l 2$ - Fig. 5 ).

The combined effect of soil temperature and water content gave a better description of the variability in soil respiration in treatment $A 12\left(R^{2}=0.48\right)$, compared to $A C 3$ $\left(R^{2}=0.43\right)$ and AT6 $\left(R^{2}=0.38\right)$. For each treatment, regression analysis resulted significant, and the parameters of the regressions were all significant (Tab. 2).

The developed models are shown in Fig. 6. The soil respiration increased with increasing of soil temperature and soil water content. When modeling $\mathrm{Al} 2$, it resulted that the increase of soil temperature and soil water content caused a higher raise in $R_{\mathrm{s}}$ compared to the other treatments.

The effects of treatments on $R_{s}$

Sphericity was assumed since Mauchly's test gave a p-value of $0.396 . R_{\mathrm{s}}$ showed large variations among the treatments $\left(F_{2 ; 36}=6.130, p<0.001\right)$. Tukey's test showed that soil respiration in Al2 was significantly higher than in $\mathrm{AC}_{3}$ and AT6. AC3 and AT6 were not significantly different.

\section{Discussion}

High temporal and spatial variation in soil $\mathrm{CO}_{2}$ efflux is a common phenomenon in forests (Curiel Yuste et al. 2007). In this study, soil respiration rates peaked in the summer $\left(4.14 \mu \mathrm{mol} \mathrm{CO}_{2} \mathrm{~m}^{-2} \mathrm{~s}^{-1}\right)$ and were lowest during spring $\left(0.72-0.88 \mu \mathrm{mol} \mathrm{CO}_{2}\right.$ $\mathrm{m}^{-2} \mathrm{~s}^{-1}$ ), when soil temperature reached the

Tab. 2 - Parameters and coefficients of the regression analysis (eqn. 4) carried out to evaluate the combined effect of soil temperature and soil water content on soil respiration in each treatment (AC3): control; (Al2): innovative treatment; (AT6): traditional treatment; (SE): standard error of the estimated parameters; (SEE): standard error estimate; (RMSE): root mean square error; $\left(R^{2}\right)$ : coefficient of determination.

\begin{tabular}{lccrccc}
\hline Treatments & Coefficient & Estimate & SE & SEE & RMSE & R $^{2}$ \\
\hline \multirow{4}{*}{ AC3 } & $b_{1}$ & 0.6413 & 0.2073 & & & \\
& $b_{2}$ & 0.0802 & 0.0127 & 0.896 & 0.846 & 0.429 \\
& $b_{3}$ & -0.0147 & 0.0025 & & & \\
& $b_{4}$ & 0.0007 & $<0.0001$ & & & \\
Al2 & $b_{1}$ & 0.5049 & 0.1539 & & & \\
& $b_{2}$ & 0.0887 & 0.0112 & 0.957 & 0.958 & 0.485 \\
& $b_{3}$ & 0.0051 & 0.0013 & & & \\
& $b_{4}$ & 0.0005 & $<0.0001$ & & & \\
AT6 & $b_{1}$ & 0.6784 & 0.2137 & & & \\
& $b_{2}$ & 0.0706 & 0.0160 & 0.886 & 0.812 & 0.383 \\
& $b_{3}$ & -0.0152 & 0.0024 & & & \\
\hline
\end{tabular}

lowest recorded values. We may hypothesize that lower soil respiration rate could result from microbial activity becoming dormant after the decline of soil temperature (Janssens \& Pilegaard 2003, Chen et al. 2010). In our study, the effect of soil moisture increased the rate of respiration for the site, when reaching $30-40 \%$ level (Fig. 4). Soil moisture directly affects microbial activity and several physical processes, such as water movement, and gas or solute diffusion (Curiel Yuste et al. 2007). Soil respiration never appeared to be inhibited by near saturated water content. These soils have high sand content, with a good structure and porosity and high infiltration rates, which result in infrequent saturated conditions. The thinning changed the moisture dynamics in Al2, thus making the response of soil respiration to changes in soil moisture more evident, especially when high temperatures occurred together with high percentage of soil water content. This is also evident from the analysis of the combined effect of soil temperature and water content on soil respiration (Fig. 6). We observed that in spring soil temperature was slightly higher in AT6 than in Al2, but this is likely to have had only a minor effect on soil respiration, which was largely constrained by low soil moisture content at that time.

Forest management practices such as thinning affect stand biomass and carbon stored in soil, influencing the interaction between the biotic (roots, invertebrates and microorganisms) and abiotic (temperature and moisture) factors of the forest ecosystem. Both increases and decreases in soil respiration after thinning have been observed in previous studies (Londo et al. 1999, Ma et al. 2004, Tang \& Baldocchi 2005, Sullivan et al. 2008), but this is due likely to the timing and duration of the measurement campaigns undertaken following thinning in the different studies.

The increase in soil respiration in the treated areas in this study could be attributed to a greater increase in heterotrophic respiration from the above- and belowground debris than the reduction in autotrophic (root) respiration (Sullivan et al. 2008). After a short time suspension of root respiration suddenly after thinning (Ekblad \& Högberg 2001), an enhancement of microbial respiration occurs when the
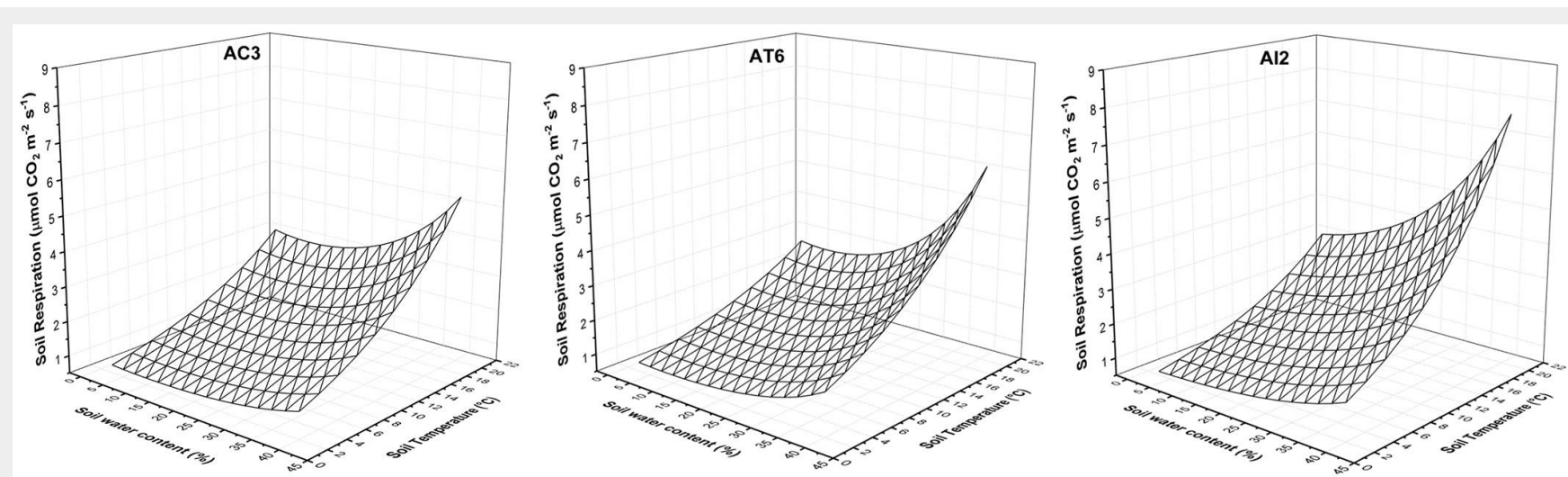

Fig. 6 - The combined effect of soil water content and soil temperature on the soil respiration in AC3 (control) AT6 (traditional), Al2 (innovative) treatments. 
decomposition of dead roots and aboveground residuals under optimum temperatures begins (Davidson et al. 2000, Hartley $\&$ Ineson 2008) and thus offsets the decline in root respiration (Ohashi et al. 2000). Thinning can also influence site specific microclimatic conditions. For example, the removal of aboveground vegetation is known to increase soil temperature, and a strong positive correlation exists between soil respiration and temperature in thinned forests (Masyagina et al. 2006, Koster et al. 2011). However, in our study soil temperature did not result to be significantly different in the three treatments, therefore we can conclude that the increase of soil respiration in $\mathrm{Al} 2$ was mainly caused by the increase of microbial respiration due to detrital decomposition, which possibly peaked when soil water content increased. The increase in soil water content may be attributed to the removal of more trees, which reduced rain interception and evapotranspiration.

$Q_{10}$ analysis gave an idea of the low influence of temperature on microbial and root respiration. This however proves the low intensity of harvesting interventions, which clearly did not lead to large gaps opening and so they can be defined low disturbance treatments. Consequently, we may expect a change of soil $\mathrm{CO}_{2}$ emission with time, as it can be inferred from the results of the analysis of the interaction between treatment and date in the ANOVA model. The interaction of treatment and date effects resulted significant $(p=0.035)$, which means that part of the variability of the data resulted from seasonal variations in the microclimatic and microsite conditions created by treatments and these variation could be detected over the all period of measurements, thus we believe different results will be derived from future measurements campaign in the same plots.

\section{Conclusions}

This study showed that the mean soil respiration increased with thinning intensity, confirming that after harvesting, detrital biomass remaining on the forest floor may contribute to raise soil respiration, also preventing evaporation of water from soil, and leading therefore to an higher microbial activity. This information is useful for forest managers in predicting the consequences of forest management given the efflux of $\mathrm{CO}_{2}$ from the soil surface of our beech forest. However, it would be interesting to carry on measurements in these sites to analyse long term post-harvest effects. Forest management practices, together with other achievements, must be oriented to enhance carbon sequestration; it is fundamental to better know the effects of forest management on $\mathrm{CO}_{2}$ cycle, considering all the components and their interactions. Therefore, studies examining patterns and mechanisms of soil $\mathrm{CO}_{2}$ in response to management practices are essential. Such studies are critical to accu- rately predict effects of forest management on the $C$ cycle and to develop appropriate forest management strategies aimed at reducing atmospheric $\mathrm{CO}_{2}$ concentrations (Peng et al. 2008).

\section{References}

Akburak S, Makineci E (2016). Thinning effects on soil and microbial respiration in a coppiceoriginated Carpinus betulus L. stand in Turkey. iForest 9: 783-790. - doi: 10.3832/ifor1810-009

Chen B, Liu S, Ge J, Chu J (2010). Annual and seasonal variations of $\mathrm{Q}_{10}$ soil respiration in the sub-alpine forests of the Eastern Qinghai-Tibet Plateau, China. Soil Biology and Biochemistry 42: 1735-1742. - doi: 10.1016/j.soilbio.2010.06.010 Cheng W, Parton WJ, Gonzalez-Meler MA, Phillips R, Asao S, Mcnickle GG, Brzostek E, Jastrow JD (2014). Synthesis and modeling perspectives of rhizosphere priming. New Phytologist 201 (1): 31-44. - doi: 10.1111/nph.12440

Conforti M, Froio R, Matteucci G, Caloiero T, Buttafuoco G (2013). Potentiality of laboratory visible and near infrared spectroscopy for determining clay content in forest soils: a case study from high forest beech (Fagus sylvatica) in Calabria (southern Italy). International Journal of Environmental Quality 11: 49-64.

Conforti M, Froio R, Matteucci G, Buttafuoco G (2015). Visible and near infrared spectroscopy for predicting texture in forest soil: an application in Southern Italy. iForest 8: 339-347. - doi: 10.3832/ifor1221-007

Curiel Yuste I, Baldocchi DD, Gershenson A, Goldstein A (2007). Microbial soil respiration and its dependency on carbon inputs, soil temperature and moisture. Global Change Biology 13: 1-18. doi: 10.1111/j.1365-2486.2007.01415.x

Davidson EA, Verchot LV, Catt'nio JH, Ackerman IL, Carvalho JEM (2000). Effects of soil water content on soil respiration in forests and cattle pastures of eastern Amazonia. Biogeochemistry 48: 53-69. - doi: 10.1023/A:1006204113917

Davidson EA, Janssens IA (2006). Temperature sensitivity of soil carbon decomposition and feedbacks to climate change. Nature 440: 165173. - doi: $10.1038 /$ natureo4514

Efron B, Tibshirani RJ (1993). An introduction to the bootstrap. Chapman and Hall, New York, USA, pp. 436.

Ekblad A, Högberg P (2001). Natural abundance of ${ }^{13} \mathrm{C}$ in $\mathrm{CO}_{2}$ respired from forest soils reveals speed of link between photosynthesis and root respiration. Oecologia 127: 305-308. - doi: 10.1007/s004420100667

Gershenson A, Bader NE, Cheng W (2009). Effects of substrate availability on the temperature sensitivity in soil organic matter decomposition. Global Change Biology 15: 176-183. - doi: 10.1111/j.1365-2486.2008.01827.x

Grace J, Rayment M (2000). Respiration in the balance. Nature 404: 819-820. - doi: 10.1038/35 009170

Hartley IP, Ineson P (2008). Substrate quality and the temperature sensitivity of soil organic matter decomposition. Soil Biology and Biochemistry 40: 1567-1574. - doi: 10.1016/j.soilbio. 2008.01.007

IPCC (2006). 2006 Guidelines for national greenhouse gas inventories. National Greenhouse Gas Inventories Programme (Eggleston HS,
Buendia L, Miwa K, Ngara T, Tanabe K eds). IGES, Hayama, Kanagawa, Japan. [online] URL: http://www.ipcc-nggip.iges.or.jp/public/2006gl/ Janssens IA, Pilegaard K (2003). Large seasonal changes in $\mathrm{Q}_{10}$ of soil respiration in a beech forest. Global Change Biology 9: 911-918. - doi: 10.1046/j.1365-2486.2003.00636.x

Kerr G (1996). The effect of heavy or free growth thinning on oak (Quercus petraea and Q. robur). Forestry $\quad 69$ (4): $303-317$.

10.1093/forestry/69.4.303

Köppen W (1936). Das geographische System der Klimate [The geographic system of climates]. In: "Handbuch der Klimatologie" (Köppen W, Geiger R eds). Gebrüder Borntraeger, Berlin, Germany, pp. 1-44.

Koster K, Puttsepp U, Pumpanen J (2011). Comparison of soil $\mathrm{CO}_{2}$ flux between uncleared and cleared wind throw areas in Estonia and Latvia. Forest Ecology and Management 262: 65-70. doi: 10.1016/j.foreco.2010.09.023

Kurth VJ, Bradford JB, Slesak R, D'Amato A (2014). Initial soil respiration response to biomass harvesting and green-tree retention in aspen-dominated forests of the great lakes region. Forest Ecology and Management 328: 342-352. - doi: 10.1016/j.foreco.2014.05.052

Kuzyakov Y, Friedel JK, Stahr K (2000). Review of mechanisms and quantification of priming effects. Soil Biology and Biochemistry 32: 14851498. - doi: 10.1016/S0038-0717(00)00084-5

Lloyd J, Taylor JA (1994). On the temperature dependence of soil respiration. Functional Ecology 8 (3): 315-323. - doi: 10.2307/2389824

Londo AJ, Messina MG, Schoenholtz SH (1999). Forest harvesting effects on soil temperature, moisture, and respiration in a bottomland hardwood forest. Soil Society of America Journal 63: 637-644. - doi: 10.2136/sssaj1999.036159950 06300030029x

Luo J, Chen Y, Wu Y, Shi P, She J, Zhou P (2012). Temporal-spatial variation and controls of soil respiration in different primary succession stage on glacier forehead in Gongga Mountain, China. PLoS ONE 7 (8): e42354. - doi: 10.1371/ journal.pone.0042354

Ma S, Chen J, North M, Erickson HE, Bresee M, Le Moine J (2004). Short-term effects of experimental burning and thinning on soil respiration in an old-growth, mixed-conifer forest. Environmental Management 33: 148-159. - doi: 10.1007/ s00267-003-9125-2

Marziliano PA, Menguzzato G, Scuderi A, Corona $P$ (2012). Simplified methods to inventory the current annual increment of forest standing volume. iForest 5 (6): 276-282. - doi: 10.3832/ifor 0635-005

Marziliano PA, Coletta V, Menguzzato G, Nicolaci A, Pellicone G, Veltri A (2015a). Effects of planting density on the distribution of biomass in a douglas-fir plantation in southern Italy. iForest 8 (3): 368-376. - doi: 10.3832/ifor1078-007

Marziliano PA, Lafortezza R, Medicamento U, Lorusso L, Giannico V, Colangelo C, Sanesi G (2015b). Estimating belowground biomass and root/shoot ratio of Phillyrea latifolia $\mathrm{L}$. in the Mediterranean forest landscapes. Annals of Forest Science 72: 585-593. - doi: 10.1007/s135 95-015-0486-5

Masyagina OV, Hirano T, Ji DH, Choi DS (2006). Effect of spatial variation of soil respiration 
rates following disturbance by timber harvesting in a larch plantation in Northern Japan. Forest Science Technology 2: 80-91. - doi: 10.1080/ 21580103.2006.9656303

Masyagina OV, Prokushkin SG, Koike T (2010). The influence of thinning on the ecological conditions and soil respiration in a Larch forest on Hokkaido Island. Eurasian Soil Science 43: 693700. - doi: 10.1134/S1064229310060104

Nocentini S (2009). Structure and management of beech (Fagus sylvatica L.) forests in Italy. iForest 2 (1): 105-113. - doi: 10.3832/ifor0499-002 Ohashi M, Gyokusen K, Saito A (2000). Contribution of root respiration to total soil respiration in a Japanese cedar (Cryptomeria japonica D. Don) artificial forest. Ecological Research 15: 323-333. - doi: 10.1046/j.1440-1703.2000.00351.x Olajuyigbe S, Tobin B, Saunders M, Nieuwenhuis $M$ (2012). Forest thinning and soil respiration in a Sitka spruce forest in Ireland. Agricultural and Forest Meteorology 157: 86-95. - doi: 10.1016/j. agrformet.2012.01.016

Peng Y, Thomas SC, Tian D (2008). Forest management and soil respiration: implications for carbon sequestration. Environmental Reviews 16: 93-111. - doi: 10.1139/A08-003

Peters GP, Davis SJ, Andrew R (2012). A synthesis of carbon in international trade. Biogeosciences 9: 3247-3276. - doi: 10.5194/bg-9-32472012

Picchio R, Spina R, Calienno L, Venanzi R, Lo Monaco A (2016). Forest operations for implementing silvicultural treatments for multiple purposes. Italian Journal of Agronomy 11: 156161.
Reichstein M, Rey A, Freibauer A, Tenhunen J, Valentini R, Banza J, Casals P, Cheng Y Y, Grunzweig JM, Irvine J, Joffre R, Law E, Loustau D, Miglietta F, Oechel W, Ourcival JM, Pereira JS, Peressotti A, Ponti F, Qi Y, Rambal S, Rayment M, Romanya J, Rossi F, Tedeschi V, Tirone G, Xu $M$, Yakir D (2003). Modeling temporal and large-scale spatial variability of soil respiration from soil water availability, temperature and vegetation productivity indices. Global Biogeochemistry Cycles 17: 1104. - doi: 10.1029/2003 GB002035

Rodeghiero M, Cescatti A (2005). Main determinants of forest soil respiration along an elevation/temperature gradient in the Italian Alps. Global Change Biology 11: 1024-1041. - doi: 10.111 1/j.1365-2486.2005.00963.x

Sampson DA, Janssens IA, Curiel Yuste J, Ceulemans $R$ (2007). Basal rates of soil respiration are correlated with photosynthesis in a mixed temperate forest. Global Change Biology 13: 2008-2017. - doi: 10.1111/j.1365-2486.2007.0141 4.x

Schlesinger WH, Andrews JA (2000). Soil respiration and the global carbon cycle. Biogeochemistry 48: 7-20. - doi: 10.1023/A:1006247623877

Seber GAF, Wild CJ (1989). Nonlinear regression. Wiley Series in Probability and Mathematical Statistics, Wiley, NY, USA, pp. 768. - doi: 10.1002 10471725315

Soil Survey Staff (2010). Keys to soil taxonomy ( $11^{\text {th }}$ edn). Natural Resources Conservation Service, USDA, Washington, DC, USA, pp. 338. [online] URL: http://www.nrcs.usda.gov/Inter net/FSE_DOCUMENTS/nrcs142p2_050915.pdf
Sullivan BW, Kolb TE, Hart SC, Kaye JP, Dore S, Montes-Helu M (2008). Thinning reduces soil carbon dioxide but not methane flux from southwestern USA ponderosa pine forests. Forest Ecology and Management 255: 4047-4055. doi: 10.1016/j.foreco.2008.03.051

Tang J, Baldocchi DD (2005). Spatial-temporal variation in soil respiration in an oak-grass savanna ecosystem in California and its partitioning into autotrophic and heterotrophic components. Biogeochemistry 73: 183-207. doi: 10.1007/s10533-004-5889-6

Trumbore SE (1997). Potential responses of soil organic carbon to global environmental change. Proceedings of the National Academy of Science USA 94: 8284-8291. - doi: 10.1073/ pnas.94.16.8284

Valentini R, Matteucci G, Dolman AJ, Schulze ED, Rebmann C, Moors EJ, Granier A, Gross P, Jensen NO, Pilegaard K, Lindroth A, Grelle A, Bernhofer C, Grünwald T, Aubinet M, Ceulemans R, Kowalski AS, Vesala T, Rannik Ü, Berbigier $P$, Loustau D, Guðmundsson J, Thorgeirsson $H$, Ibrom A, Morgenstern K, Clement R, Moncrieff J, Montagnani L, Minerbi S, Jarvis PG (2000). Respiration as the main determinant of carbon balance in European forests. Nature 404 (6780): 861-865. - doi: 10.1038/35009084 Zhu B, Cheng W (2011). Rhizosphere priming effect increases the temperature sensitivity of soil organic matter decomposition. Global Change Biology 17: 217-218. - doi: 10.1111/j.13652486.2010.02354.x 